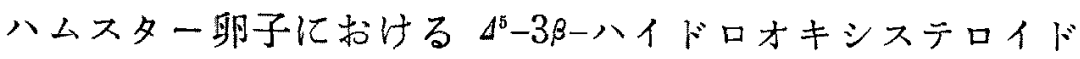 脱水素醉素の組織化学的研究
}

\author{
新村末雄・石田一夫 \\ 新潟大学農学部, 新潟市 $950-21$
}

(1976. 9. 30 受付)

\begin{abstract}
要 約 発生初期のハムスター卵子について 17 $\alpha$-hydroxypregnenolone 基質として $\Delta^{5}-3 \beta$-hydroxysteroid dehydrogenase 活性を組織化学的に検出したところ，未受精卵子，ならびに精子侵入期およ び前核期の卵子においては強い活性が错察された。前 2 者の卵子にはジホルマザン顆粒が細胞質に一様 に分布しており，後者の卵子には核の周辺に特に多く観察された。醳菜活性は 4 細胞期宗で強かった が，8細胞期に至り急激に弱まった。分割卵子においては，ジホルマザン顆僬は分割球の核の周辺子細 胞質の表層に特に多く分布していた．胞胚には醉菜活性は全くみられなかった：これらの結果から，1 細胞期から 8 細胞期までの八ムスター卵子においては，17 progesterone 人の転換ぶ見られるが，胞肧ではこの転換は見られないこと驾推察された。
\end{abstract}

DickMann と共同研究者は1ー7), 1973 年加ら 1975 年に がて、ラットハムスターおよびウサギの卵子について dehydroepiandrosterone (DHA) を基質に朋いて $\Delta^{5}$ $3 \beta$-hydroxysteroid dehydrogenase $\left(\Delta^{5}-3 \beta\right.$-HSD) $の$ 組 織化学的検出老試み，この酵素活性は分割朋子が胞肧に 変形する時期に初めて出現することを観察し，この㭙期 の卵子がステロイトホルモンの産生能它持っていること を示晙した，その後，著者 ${ }^{8,91}$ も発生初期の川ムスタ一 卵子について, $\Delta^{5}-3 \beta-H S D$ (DHA と pregnenolone 質に使用)，17 $\beta$-hydroxysteroid dehydrogenase (estra-

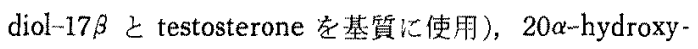

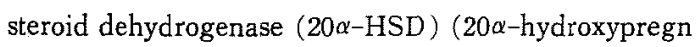
-4-en-3-one 老基質に使用) および 20

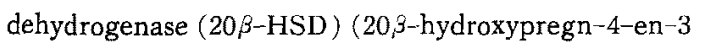
一one c基筫飞使用) 組織化学的に検出し，これらの 酤素は排卵直後から胞胚期丈での畉子に常に存在してい ること艺報告した，特に，pregnenolone を基質とした

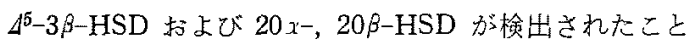
加ら，卵子に progestagen の産生能のあること示咬

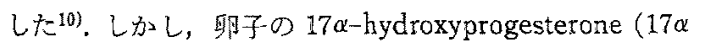
-OH-P) の産生に関寸る酵素組織化学的研究は文献上い まだ見いだされない，本実験は発生初期の八ムスタ一卵 子について, 17 $\alpha$-hydroxypregnenolone 基劦に用いて

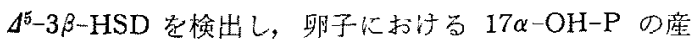
生能を検討したものである。

\section{材料および方法}

供試愺物として，体重 100-120 g の八厶大タ一 (Mesocricetus auratus) 党使用した。，八ムスターの飼育

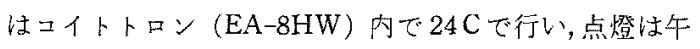
前 4 時加方午後 6 時までの14時間とした。 まず, post -

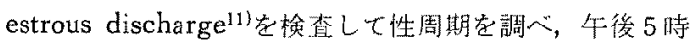
から6時をでの間に発情を開始したハムスターを用い た. 八ムスターは発情開始後約 8 時間で排卵することが 報告されているので12，卯子の時龄は発情の開始基潐

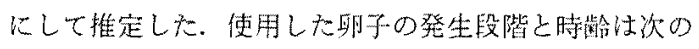
通りである.すなっる，末受精卵子は排卵後 2 時間，精 子侵入期の卵子は 4 時間，前核期の卵子沬 11 時間，2 細 胞嵧子は 32 時間， 4 細胞卵子は 52 㭙間，8細胞卵子は

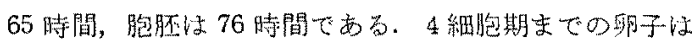

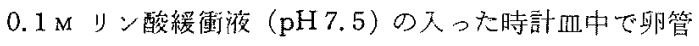

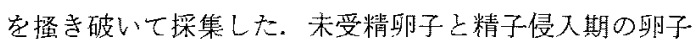
は $0.1 \%$ ヒルロニダーゼ水溶液によって卵丘細胞を解

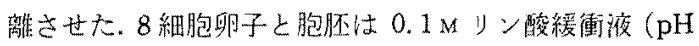
7.5）で子宮をかん流して棌集した。邪子の形態は必要に 応じて位相差顐微鏡で輖鏡した。

観察しれ酵素注 $17 \alpha$-hydroxypregnenolone 基質と した $A^{5}-3 \beta$-HSD で，基貿液の組成は DickMAnN 上 $\mathrm{DEY}^{1 〉}$ の使用したステロイド脱水亲醉素検出のための処

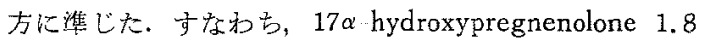



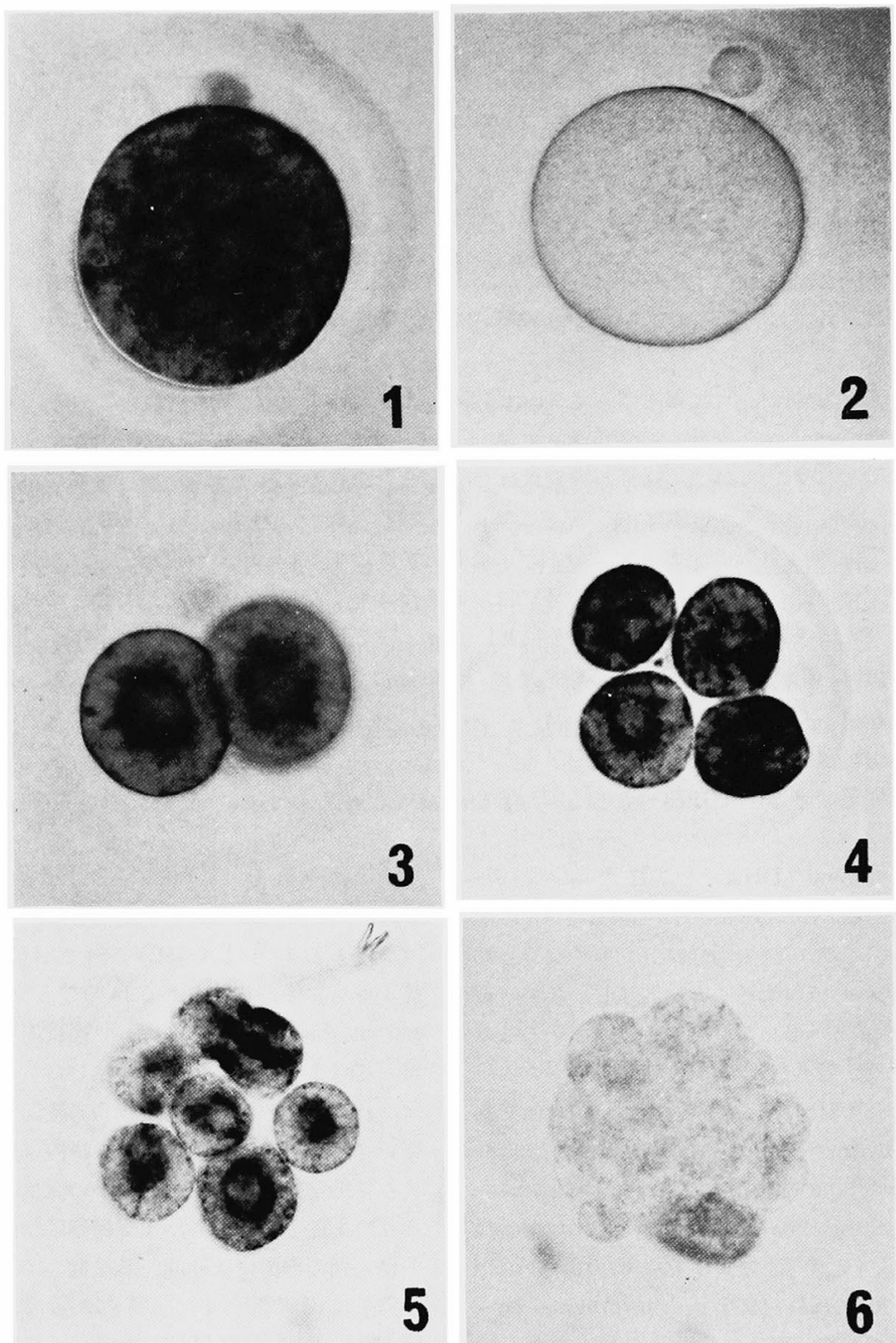

5

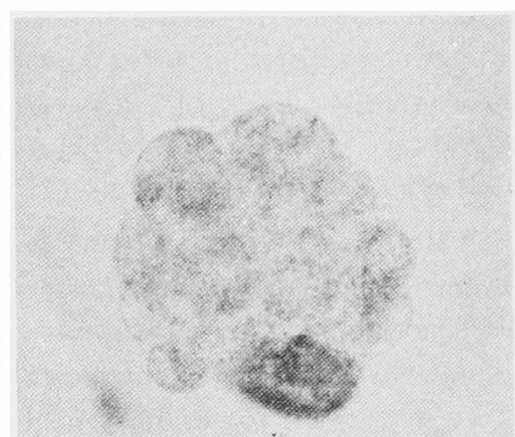

\section{Explanation of Figures}

Eggs in Figures $1,3,4$ and 5 show various levels of $4^{5}-3 \beta$-hydroxysteroid dehydrogenase activity when incubated in a medium containing $17 \alpha$-hydroxypregnenolone as a substrate, but the egg in Figure 6 shows no activity. The egg in Figure 2 also shows no activity, since it was incubated in a medium without the substrate. Magnification $\times 250$.

Fig. 1. A pronuclear egg, 11 hours after ovulation.

Fig. 2. An unfertilized egg, 2 hours after ovulation.

Fig. 3. A 2-cell egg, 32 hours after ovulation.

Fig. 4. A 4-cell egg, 52 hours after ovulation.

Fig. 5. An 8-cell egg, 65 hours after ovulation.

Fig. 6. A blastocyst, 76 hours after ovulation. 
$\mathrm{mg}, \mathrm{NAD} 4.0 \mathrm{mg}$, Nitro-BT $2.0 \mathrm{mg}, 0.1 \mathrm{M}$ リン酸䌅 衝液（pH 7.5） $10 \mathrm{ml}$ で，基質はあら汃じめ $0.5 \mathrm{ml}$ の dimethylformamide に溶解して使用した。浸漬は37Cで 行い，酵素活性は卵子にジホルマザン顆粒の沈着が出現 するまでの時間によって判定した。すな⿰七, 漫清後 60 分玉でにジホルマザン顆粒が沈着したすの空䤃素活性强 度とし,90分までのすの中等度, 120 分までのすのを 弱度とした．また，120分の漫漬でジホルマザン顆粒の

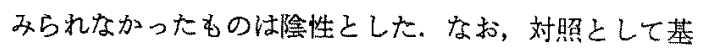

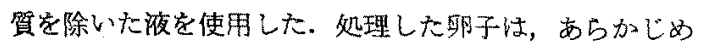
ワセリン・ハララフィンをカバーグラスの四隅に位置する ように扎たスライドグラスの中央に移し，カバーグラ スをから゙せて静かに卵子を圧し，顕微鏡下で観察した。

\section{結果}

17 $\alpha$-hydroxypregnenolone を基質にして $A^{5}-3 \beta-H S D$ 它組織化学的に検出したところ，即子の細胞質にジホル マザン顆粒の沈着が文られた（Fig、1)。この顆精は基丝 を除いた液に浸清した即子には出現しなかったので (Fig. 2)，ジホルマザン顆粒は䤃素活性を現わしている ことが確認された.

未受精および精子侵入期の卵子において，ジホルマザ ン顆䊀は細胞質全域にわたって一様に分布しており，前 核期の卵子では核の周辺に特に多く見られた（Fig. 1). 末受精卵子の第 1 極体にはジホルマザン顆粒が見られた が，精子侵入期に至り消失した。一方，この顆粒は精子 侵人期に放出された第 2 極体にも出現したが，間もなく 消失した. 2 ないし 8 細胞期の卵子に和いて，ジホルマ ザン顆粒は分割球の核の周辺之細胞質の表層に特に多く 分布していた (Figs. 3-5). 透明帯はいずれの時期にお いてもジホルマザン顆粒の出現を示さなかった。すをお 方，透明帯での酵素活性は認められなかっった。

それぞれの発生段階の率における $4^{5}-3 \beta-H S D$ 活性
は Table 1 に示劣通りである。字なる，この活性は 4 細胞期までは強かったが，8細胞期に至って著しく弱ま り，活性が全く見られない即子す現われた。胞胚期では 酵素活性は全く検出されなかった（Fig.6).

考察

ササギの胞胚には progesteroneが含まれており，胞胚

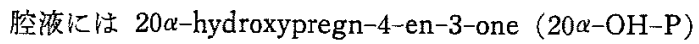

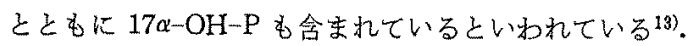
Sugawara と TAKEUCHI ${ }^{14}$ はトリキウム $\left.{ }^{3} \mathrm{H}\right]$ をラベルし た progesterone をウサギに注射すると，それは胞胚腔

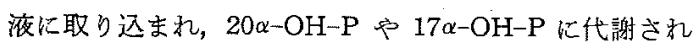
ること報告した。これらの progestagen の合成に關与 している脱水素酵素については，最近，著者ら ${ }^{10) か ゙ ハ ム ~}$ スター卵子を用いて組織化学的に調ベたとこる, pregnenolone 基質とした $\Delta^{5}-3 \beta-\mathrm{HSD}$ と $20 \alpha-\mathrm{OH}-\mathrm{P}$ 基翼とした $20 \alpha-H S D$ が排卵直後から胞胚期に至るすべ ての卵子に检出された。このことから，著者らは八厶スタ

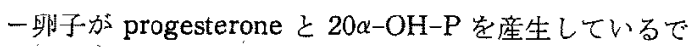

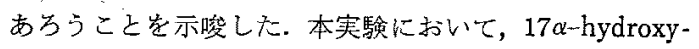
pregnenolone を基質とした $\Delta^{5}-3 \beta-H S D$ の活性は排 卵直後から8細胞期むで存在しているが，胞胚期では見 られないことが明らかとなった。このことから，8細胞 期までの八ムスター卵子は $17 \alpha$-hydroxypregnenolone から $17 \alpha-\mathrm{OH}-\mathrm{P}$ への転換を行っているが，胞胚ではこ の転換を全く行っていないことが推察された.したがっ て, 著者らのこの研究結果と, 従来の報告の結果と省合 わせ考えると，八ムスタ一の卵子においては，8細胞期 までは progesterone と $17 \alpha$-hydroxypregenenolone か

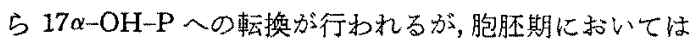
progesterone $力$ b $17 \alpha-\mathrm{OH}-\mathrm{P}$ 人の転換はるが, $17 \alpha-$ hydroxypregnenolone から $17 \alpha-\mathrm{OH}-\mathrm{P}$ への転換はない ように思わ机。

Table 1. The activity of $A^{5}-3 \beta$-hydroxysteroid dehydrogenase in hamster eggs incubated in a medium with $17 \alpha$-hydroxypregnenolone as a substrate

\begin{tabular}{lccccccc}
\hline $\begin{array}{l}\text { Enzyme } \\
\text { activity }\end{array}$ & $\begin{array}{c}\text { No. of } \\
\text { unfertilized } \\
\text { eggs }\end{array}$ & $\begin{array}{c}\text { Sperm- } \\
\text { penetrated }\end{array}$ & Pronuclear & 2-cell & 4-cell & 8-cell & Blastocyst \\
\hline Strong & 24 & 56 & 55 & 31 & 30 & 0 & 0 \\
Moderate & 21 & 10 & 0 & 0 & 0 & 0 & 0 \\
Weak & 12 & 0 & 0 & 0 & 0 & 19 & 0 \\
Absent & 0 & 0 & 0 & 0 & 0 & 8 & 26 \\
\hline $\begin{array}{l}\text { Total number of } \\
\text { eggs examined }\end{array}$ & 57 & 66 & 55 & 31 & 30 & 27 & 26 \\
\hline
\end{tabular}


従来, ウサギの胞肧に存在しているといわれて来た $17 \alpha-\mathrm{OH}-\mathrm{P}^{19)}$ は， 八ムスターの卵子とウサギの即子との 間に $17 \alpha-\mathrm{OH}-\mathrm{P}$ への転愌経路に関して差異がないすの 之仮定すれば，17 $\alpha$-hydroxypregnenolone 加ら転換され たものではなく, progesterone から転換されたものであ ろうということが推察される。

\section{文献}

1) Dickmann, Z., and S. K. Dey, J Reprod Fert 35: 615-617. 1973.

2) Dickmann, Z., and S. K. Dey, J Endocrinol 61: 513-514. 1974.

3) Dickmann, Z., and S. K. Dey, J Reprod Fert 37: 91-93. 1974.

4) Dey, S. K., and Z. Dickmann, Endocrinology 95: 321-322. 1974.
5) Dickmann, 2., S. K. Dey, and J. S. Gupta, Proc Nat Acad Sci 72: 298-300. 1975.

6) Drckmann, Z., S.K. Dex, and J.S. Gupta, Anat Rec 181: 346-347. 1975.

7) Dickmann, Z., and J.S. Gupta, Devel Biol 40: 196-198. 1974.

8）新村末雄・石田一夫, 家畜慗殖誌 22：13-17.1976.

9）新村末雄・石田一夫, 家畜繁殖誌 22：55-59.1976.

10) Nimmura, S., and K. Ishida, J Reprod Fert 48: 275-278. 1976.

11) Orsini, M. W., Proc Animal Care Panel 11: 193206. 1961.

12 Harvey, E. B., R. Yanagimachi, and M. C. Chang, J Exp Zool 146: 231-235. 1961.

13) Seamark, R. F., and C. Lutwak-Mann, J Reprod Fert 29: 147-148. 1972.

14) Sugawara, S., and S. Takeuchi, Excerpta Medica Internat Cong Ser No. 234: 44. 1971.

\title{
Histochemical Studies of $\Delta^{5}-3 \beta-$ Hydroxysteroid Dehydrogenase in Hamster Eggs
}

\author{
Sueo Ninmura and Kazuo IshidA
}

Faculty of Agriculture, Niigata University, Niigata-shi 950-21

The activity of $4^{5}-3 \beta$-hydroxysteroid dehydrogenase in hamster eggs at the preimplantation period was investigated by a histochemical method using $17 \alpha$-hydroxypregnenolone as a substrate. Eggs were obtained at different developmental stages: unfertilized eggs 2 hours after ovulation, sperm-penetrated eggs 4 hours, pronuclear eggs 11 hours, 2-cell eggs 32 hours, 4-cell eggs 52 hours, 8-cell eggs 65 hours, and blastocysts 76 hours. Histochemical demonstration of the enzyme was made by the Dickmann and Dey method for steroid dehydrogenase. The composition of the medium was $1.8 \mathrm{mg} 17 \alpha$-hydroxypregnenolone, $4.0 \mathrm{mg} \mathrm{NAD}, 2.0 \mathrm{mg}$ Nitro-BT and $10 \mathrm{ml} 0.1 \mathrm{~m}$ phosphate buffer solution. A strong enzyme activity was observed in unfertilized, sperm-penetrated and pronuclear eggs; diformazan granules were distributed evenly throughout the cytoplasm of the unfertilized and sperm-penetrated eggs; while in the pronuclear eggs, they were especially abundant in the perinuclear region. The intensity of the enzyme activity was retained until the eggs reached the 4-cell stage, but was then weakened at the 8-cell stage. In cleaved eggs, diformazan granules were especially abundant in the perinuclear region and the outer layer of the cytoplasm. No enzyme activity was found in the blastocysts. From these results, it seems that conversion of $17 \alpha$-hydroxypregnenolone to $17 \alpha$-hydroxyprogesterone occurs in hamster eggs at the 1 - to 8 -cell stages, but does not occur in the blastocysts. 